\title{
A DIACRONIA DO ENCONTRO DE ULISSES COM O CICLOPE NO REPERTÓRIO ICONOGRÁFICO "LYCHNOLÓGICO"
}

\author{
Carlos Pereira / Pedro Albuquerque \\ UNIARQ-Universidade de Lisboa \\ carlos_samuel_pereira@hotmail.com/skapedroalbuquerque@gmail.com
}

\section{DIACHRONY OF THE MEETING OF ULYSSES WITH THE CYCLOPS IN THE LYCHNOLOGICAL ICONOGRAPHIC REPERTOIRE}

RESUMEN: Este trabalho pretende analisar as representações do encontro de Ulisses com Polifemo numa perspectiva diacrónica, ao mesmo tempo que se apresentam interpretações possíveis sobre a sua representação iconográfica nas lucernas. Antes de analisar a tipologia e a cronologia destas lucernas, tecemos algumas considerações que julgamos importantes para a interpretação de uma narrativa "lychnológica", plasmada em diferentes relevos. A longevidade da reprodução literária e iconográfica das façanhas de Ulisses é um indício claro da sua importância nos contextos culturais helénico e romano. Das várias formas de transmissão, entre elas a via oral, não devemos esquecer a importância da arte como veículo de propagação de conhecimento.

PALABRAS CLAVE: lucernas romanas, AltoImpério, iconografia, Ulisses, Polifemo.

\begin{abstract}
The purpose of this paper is to present an interpretation for the iconography of Odysseus' encounter with Polifemus, in a diachronical perspective. At the same time, we tend to present possible interpretations for the iconography of roman lamps. We discuss, before a typological and chronological analysis of these lamps, some important questions for the interpretation of a lychnological narrative, which manifests itself in different reliefs. Diachronically, the literary and iconographical reproduction of Odysseus' exploits reveals its importance in the Hellenic and Roman contexts. The transmission of these Homeric episodes, in oral or written record, cannot make us forget the importance of Art in the dissemination of knowledge.
\end{abstract}

KEYWORDS: Roman lamps, High-Empire, Iconography, Odysseus, Polyphemus. 
INTRODUÇÃO

Pero, jea!, pon mente a esto otro y explica fielmente./ ¿Por qué sitios viajaste errabundo? ¿A qué tierras llegastel y que pueblos has visto o ciudades de buena vivienda,/ ya habitados por hombres malvados, groseros, injustos/ o benignos al huésped, con sano temor de los dioses?

Od. $8.572-576^{1}$

$\mathrm{Na}$ Odisseia, a descrição do encontro entre Odisseu ou Ulisses e Polifemo surge na sequência deste "pedido" de Alcínoo, que estrutura toda a narrativa do protagonista desta longa viagem de regresso a Ítaca. O sucesso posterior deste episódio reflectiu-se na produção literária e, como será aqui discutido, na iconografia das lucernas ${ }^{2}$. No entanto, entre aquela obra e estes materiais existe todo um percurso de recepção e reprodução que importa analisar numa perspectiva diacrónica.

O dito percurso inicia-se, obviamente, no relato homérico e no modo como o Ciclope Polifemo desempenha um importante papel no conjunto da narrativa de Ulisses. Não obstante os vários problemas que envolvem o poema, as representações iconográficas nas cerâmicas gregas incidem sobre dois momentos-chave do encontro entre as personagens: quando o herói cega o seu opositor e quando aquele e os seus companheiros fogem da caverna. Neste sentido, estamos perante um elemento iconográfico tal como foi visto por quem o produziu e por quem o adquiriu. Podemos, porém, não saber ao certo o modo como o artista e o comprador interpretaram o episódio para, a partir daí, definir, com as naturais limitações dos signatários, a sua importância para o fabrico de lucernas.

Este é, sem dúvida, um dos desafios deste trabalho, uma vez que a recepção de um relato ou, como neste caso, de um conjunto iconográfico, é determinada pelo contexto do observador. O episódio de Polifemo faz parte de um vasto e interessante conjunto de representações da Odisseia nas lucernas romanas: o naufrágio de Ulisses (Canto V), o encontro com Circe (Canto X), a passagem pelo lugar das sereias (Canto XII), entre outras que foram compiladas por Amaré Tafalla ${ }^{3}$. Não é, portanto, um caso isolado, mas parece colocar alguns problemas, sobretudo ao nível do(s) significado(s) que era(m) atribuído(s) ao episódio ou, em última instância, às personagens.

No que diz respeito, por exemplo, às cerâmicas a partir do séc. VII a.C., é importante definir o método narrativo da representação ${ }^{4}$ para propor uma

\footnotetext{
${ }^{1}$ Trad. J. M. Pabón (Madrid 2006, Gredos).

${ }^{2}$ Sobre a importância do episódio na iconografia das cerâmicas áticas, cf. T. H. Carpenter, Art and Myth in Ancient Greece (London 2002) 233.

${ }^{3} \mathrm{M}^{\mathrm{a}} \mathrm{T}$. Amaré Tafalla, "Representaciones literarias sobre lucernas romanas", XVII Congreso $\mathrm{Na}$ cional de Arqueología (Zaragoza 1985) 739-748.

${ }^{4}$ Mono-cénico (uma só cena do episódio), sinóptico (várias cenas que representam momentos diferentes dos episódios), cíclico (conjuntos de cenas, fisicamente separadas, do mesmo episódio) ou
} 
explicação para a escolha de uma passagem do episódio em detrimento de outras. É, por isso, necessário apresentar um pequeno resumo do relato para que possamos compreender as razões que presidiram a estas escolhas: se, por um lado, a valorização da passagem em si (e aí é necessário determinar um objectivo nessa transmissão) ou se, por outro, a utilização de momentos que permitem individualizar e reconhecer o episódio.

É neste sentido que ganha particular importância um breve apontamento à representação literária destes seres na literatura grega e latina. O nome Ciclo-

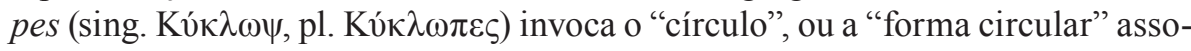
ciada, mormente, ao olho, como adverte, por exemplo, Hesíodo5. Esta referência sugere que os Ciclopes teriam um único olho (figs. 1-3?), mas isto não parece ser explícito na Odisseia ${ }^{6}$, levando a pensar que se trata de uma concepção que remete para a forma dos olhos ${ }^{7}$.

A tradição literária grega acabou por criar um conjunto interessante de variáveis que foram assinaladas por Helânico, no início do séc. IV a.C. ${ }^{8}$, justificando em boa medida o porquê de se ter utilizado o nome dos Ciclopes para designar uma técnica de construção9. Kúk $\lambda \omega \pi \varepsilon \varsigma$ eram também três filhos de Urano e $\mathrm{Geia}^{10}$, que foram fechados pelo pai no Tártaro e, posteriormente, libertados por Zeus. Este tema pode ser desenvolvido noutra ocasião, mas por agora importa assinalar Polifemo, o mais conhecido destes Ciclopes e, sem grande margem para dúvida, aquele que perdurou durante mais tempo no imaginário colectivo, tanto na Grécia como em Roma.

A julgar por uma passagem da Ilíada ${ }^{11}$, Polifemo lutou contra os Centauros, desempenhando um papel central na narrativa da Odisseia, uma vez que o seu cegamento desencadeou a ira de Possídon, dando início a todas as peripécias do

contínuo (variante do método cíclico, mas sem separação de cenas). Cf. H. A. Shapiro, Myth into Art. Poet and Painter in Classical Greece (London-New York 1997) 8.

${ }^{5}$ Th. 144-145: "La denominación de 'Cíclope' se debía a que, efectivamente, en su frente había

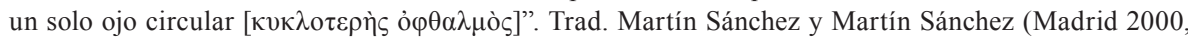
Akal). Cf. R. Mondi, “The Homeric Cyclopes: Folktale, Tradition, and Theme”, TAPhA 113 (1983) 21.

${ }^{6}$ Cf. Od. 9.380ss.; M ${ }^{\mathrm{a}}$ I. Rodríguez López, "Iconografía de Polifemo: la tradición homérica y sus pervivencias", Cuadernos de Filología Clásica. Estudios griegos e indoeuropeos 20 (2010) 181. Veja-se, igualmente, a importante reflexão de R. Mondi, "The Homeric Cyclopes...".

${ }^{7}$ Cf. C. Walde, "Cyclopes", Brill's New Pauly 3 (2003) 1042-1043.

${ }^{8}$ FGrH, 4, fr. 88: "ceux qui ont fortifié Mycènes, les compagnons de Polyphème et les dieux eux mêmes", ap. I. Aurenti, "Figures de Cyclopes dans la Rome Antique", Incontri triestini di filologia classica 4 (2004-2005) 31-47. Note-se que este texto é posterior às representações gregas mencionadas neste trabalho.

${ }^{9}$ Pind. fr. 169 Snell; Ferécides, FGrH 3, fr. 12. Cf. M. Ostwald, "Pindar, Nomos, and Heracles: (Pindar, Frg. 169 [Snel12]+POxy. No. 2450, Frg. I)”, HSCPh 69 (1965) 109-138. Uma visão de síntese em C. Walde, "Cyclopes"... A designação só foi aplicada a partir do momento em que se abandonou a técnica de construção.

${ }^{10}$ Hes. Th. 139-146; Verg. Aen. 8.416-453, etc.

${ }^{11} 1.264 \mathrm{ss}$. 
herói. Polifemo é filho daquela divindade e de uma ninfa (Thoosa), o que contradiz a informação transmitida por Hesíodo sobre os Ciclopes ${ }^{12}$. Em todo o caso, a longa descrição homérica parece indicar a existência de um mundo de pastores, sem agricultura, enfim, de um espaço habitado por seres diferentes dos "homens comedores de pão"13. O modo como o Ciclope consome o vinho (puro, ao contrário das personagens homéricas, que misturam água) parece ser um elemento fundamental para lhe atribuir um carácter mais "selvagem" em oposição ao protagonista ${ }^{14}$. Trata-se, para todos os efeitos, do lado "incivilizado" da prole de Possídon.

$\mathrm{O}$ encontro entre estas duas personagens é um momento de extremo interesse na narrativa homérica. Depois de pilhagens na terra dos Cícones e de uma passagem pela dos Lotófagos ${ }^{15}$, Ulisses e os companheiros chegaram à terra dos "ferozes" Ciclopes, deparando-se com uma paisagem rica, mas sem cultivar, habitada por seres sem lei, sem justiça, que viviam em grutas ${ }^{16}$. Com doze homens e um odre de couro com vinho, Ulisses chegou à gruta de Polifemo. Não encontrando aí ninguém, sentaram-se para comer os queijos e esperar a chegada do "anfitrião". Ao chegar, este fechou a entrada da gruta com um rochedo, encurralando os protagonistas. Ulisses, face a esta situação, engendrou um ardil: ofereceria vinho a Polifemo como dádiva de hospitalidade e apresentar-se-ia com o nome de "Ninguém". O Ciclope acabou por ficar rapidamente embriagado ao consumir o vinho, adormecendo. Com isto, o herói e os companheiros protagonizam a primeira cena-chave da narrativa: o cegamento de Polifemo com o tronco de Oliveira incandescente, ao qual se segue a segunda cena, i.e., a fuga sob o ventre das ovelhas ${ }^{17}$.

Estas duas cenas são fulcrais na individualização do episódio na iconografia, mas as variantes permitem afirmar que as características de Polifemo, particularmente ao nível dos olhos, remetem para várias tradições e não apenas a de Hesíodo ou Homero (v. tabela 1). Tanto o cegamento de Polifemo como a fuga de Ulisses são temas presentes nos exemplares mais antigos, datados de c. 670 a.C.: o primeiro (cegamento), numa ânfora idenficada em Elêusis ${ }^{18}$, e o segundo (fuga),

${ }^{12}$ Cf. R. Mondi, “The Homeric Cyclopes...”, 17-19.

${ }^{13}$ Cf. F. Hartog, Mémoire d'Ulysse: Récits sur la frontière en Grèce Ancienne (Paris 1996).

${ }^{14} \mathrm{Vid}$., no entanto, as importantes reflexões de P. Pucci: "El yo y el otro en el relato de Ulises sobre los Ciclopes", Revista de Occidente 140 (1993) 119-142. Segundo este autor, Ulisses e os companheiros quebram o protocolo da hospitalidade (ou seja, entram sem serem convidados) e assumem o papel de ladrões, não de hóspedes. Polifemo podia, neste contexto, conhecer as regras da hospitalidade, uma vez que reconheceu o desrespeito.

${ }^{15}$ Od. 9.39-41 e 82-104, respectivamente.

${ }^{16} \mathrm{Od}$. 9.105ss. É neste contexto que Ulisses parece dar resposta ao pedido de Alcínoo (Od. 8.572576): "Mis leales amigos, quedad los demás aquí quietos / mientras voy con mi nave y la gente que en ella me sigue / a explorar de esos hombres la tierra y a ver quiénes sean, / si se muestran salvajes, crueles, sin ley ni justicia, / o reciben al huésped y sienten temor de los dioses" (Od. 9.172-176).

${ }^{17}$ É entre uma e outra cena que se assinala o ardil do nome. Quando os outros Ciclopes perguntam a Polifemo o que se passa, este responde: "¡Oh queridos! No es fuerza. Ninguno me mata por dolor” (Od. 9.408).

${ }^{18}$ LIMC, s.u. Kyklops, $n^{\circ} 17 /$ s.u. Odysseus, $n^{\circ} 94$. 
num oinochoe identificado em Egina ${ }^{19}$, ambos proto-áticos. No caso da ânfora, a cena foi pintada no colo do recipiente, num espaço por si só bastante limitado ${ }^{20}$. Ulisses parece surgir em grande destaque, uma vez que a sua figura é representada a branco, ao contrário dos restantes protagonistas ${ }^{21}$. A boca de Polifemo, por sua vez, sugere que o pintor procurou representar o grito de dor que é descrito em Od. 9, 395-396, embora esteja em posição de descanso (i.e., embriaguez).

É, no entanto, nas cerâmicas áticas de figuras negras que este tema ganha um grande destaque (i.e., a partir de 570 a.C.), adquirindo uma extraordinária riqueza devido às variações feitas pelos pintores em relação ao relato ${ }^{22}$.

Uma dessas representações (fuga), datada de 570-560 a.C., parece destacar a bestialidade de Polifemo (cabelos compridos e pêlos sugeridos pelas linhas brancas oblíquas), do mesmo modo que a sua cegueira, sugerida pela posição das mãos e pelo(s) olho(s) fechado(s ${ }^{23}$. Ao contrário de outros exemplos, o tamanho desta personagem não é muito desproporcionado face ao de Ulisses. Isto ocorre na fig. 1 e na fig. 3, esta última uma taça espartana que, curiosamente, apresenta três cenas numa só (i.e., com método sinóptico): Polifemo come os companheiros de Ulisses (a julgar pelas pernas que o monstro segura), é embriagado (krater) e, finalmente, é atingido pelo ramo que lhe cega, aparentemente, o olho direito (o esquerdo mantém-se aberto: compare-se com a fig. 1).

Esta concepção de Polifemo, como um ser com dois olhos que é atingido no lado direito com um ramo, acaba por ser predominante. Isto é confirmado com uma cena representada num skyphos de figuras negras atribuído ao pintor de Teseu (c. 500 a.C.: fig. 4), em que a personagem "olha" para o observador, ao contrário de outras situações, em que é apresentada de perfil ${ }^{24}$. É, por este motivo, um documento único que permite questionar com maior acerto os restantes exemplares que reproduziram, como veremos, este episódio ao longo de vários séculos ${ }^{25}$.

${ }^{19}$ T. H. Carpenter, Art and Myth..., fig. 342.

${ }^{20}$ H. A. Shapiro, Myth into Art..., 51 e figs. 30-31. O autor defende que o facto de se localizar no colo indica que o pintor pretendia transmitir uma sensação de claustrofobia. Veja-se, igualmente, LIMC, s.u. Kyklops, n 17; T. H. Carpenter, Art and Myth..., fig. 340; J. Boardman, Athenian Black Figure Vases (London-New York 1997) fig. 1.

${ }^{21}$ Cf. H. A. Shapiro, Myth into Art..., 51.

${ }^{22}$ Esta questão merece desenvolvimento numa outra ocasião e com uma perspectiva mais global, questionando, por exemplo, até que ponto estas variações são resultado dos contributos, ou das percepções, dos artistas, ou se estamos, efectivamente, perante tradições diferentes. A isto acrescenta-se a análise destes aspectos a partir da transmissão e/ou alteração dos textos ao longo dos tempos. Ou tratar-se-ia, simplesmente, de uma opção estética?

${ }^{23}$ LIMC, Kyklops, no 19 (Krater de figuras negras atribuído a Clítias, de c. 570-560 a.C.). Apresenta inscrição com o nome O $\lambda v \tau \varepsilon v \varsigma$ (i.e., Odysseus). O olho direito está voltado para o observador, ao contrário de outras representações, em que Polifemo é ferido, sistematicamente, no olho direito. Os animais (peixe e serpente) representados não são importantes para a representação da narrativa.

${ }^{24}$ LIMC, Kyklops, $\mathrm{n}^{\mathrm{o}} 22$ (Berlin, Antikensammlung, $\mathrm{n}^{\mathrm{o}} 306788$ ).

${ }^{25}$ L. Giuliani, Image and Myth. A History of Pictorial Narration in Greek Art (Chicago-London 2013) $136-137$. 


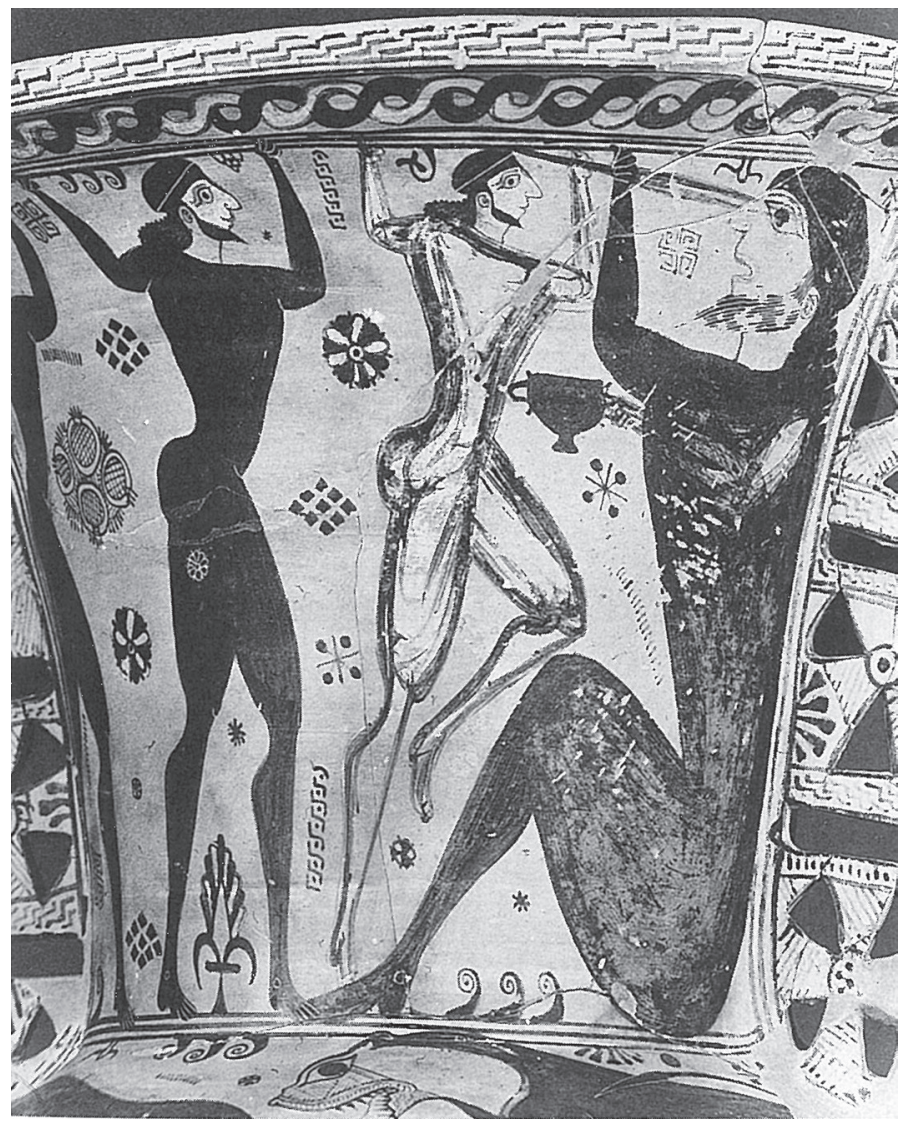

Figura 1. LIMC, K. 17: c. 670 a.C., ânfora protoática (Carpenter, 2002, fig. 340; Boardman, 1997, fig. 1; Shapiro, 1997, fig. 30-31).

Colocam-se, porém, outras questões. A primeira relaciona-se com a fonte de inspiração: se, por um lado, esta iconografia se inspira na Odisseia homérica ou no Ciclope, de Eurípides, ou se, por outro, noutros testemunhos orais e iconográficos. Atendendo a outro krater recolhido no LIMC, de 410 a.C., a presença dos sátiros na cena sugere que se trata, efectivamente, da recordação dessa obra e não da Odisseia ${ }^{26}$. A segunda interrogação prende-se com as razões que levaram ao êxito desta narrativa no imaginário grego e, posteriormente, no romano, como veremos no âmbito das lucernas. Para responder a esta última interrogação, há que considerar o modo como Polifemo é visto e pensado pelo artista, uma vez que isso pode determinar a escolha da parte da sequência narrativa e a caracterização das personagens. Há, igualmente, que considerar a chamada "questão homérica", que envolve a autoria, a cronologia, a fixação por escrito e a possível génese da Odisseia em tradições orais.

${ }^{26}$ s.u. Kyklops/ Kyklopes, $n^{\circ} 27$. Polifemo tem três olhos. Sobre a relação entre esta representação e o Ciclope de Eurípides, veja-se T. H. Carpenter, Art and Myth..., 234. 


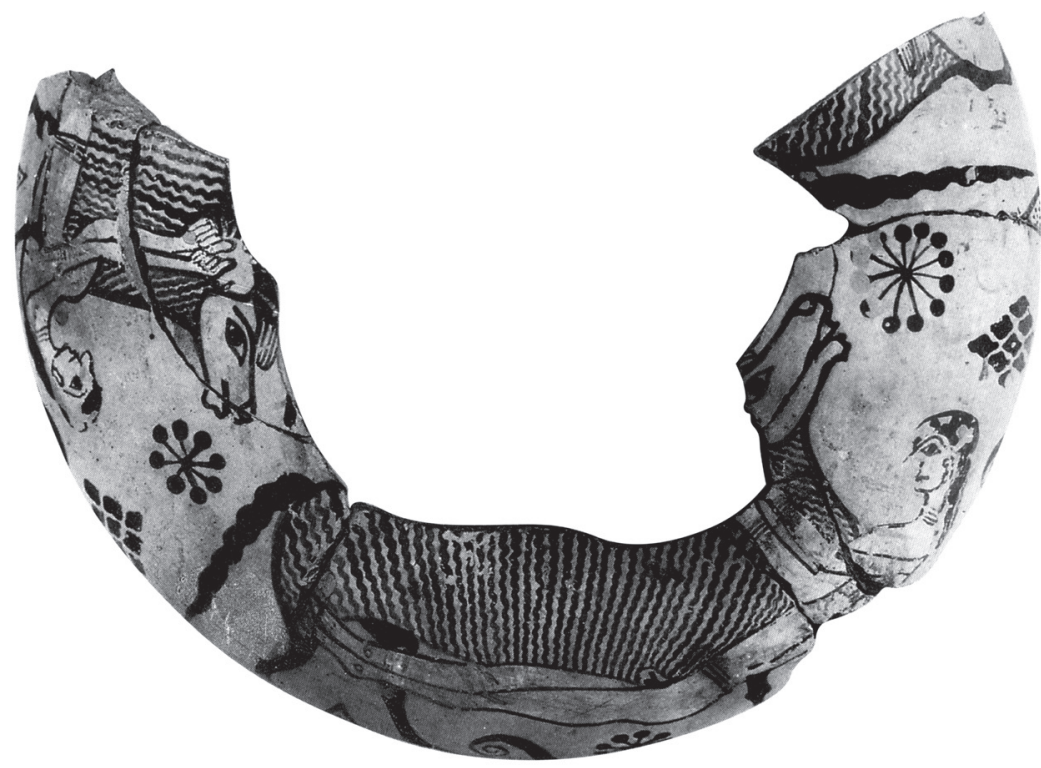

Figura 2. Carpenter, 2002, fig. 342: c. 670 a.C. (Oinochoe proto-ático de Aegina).

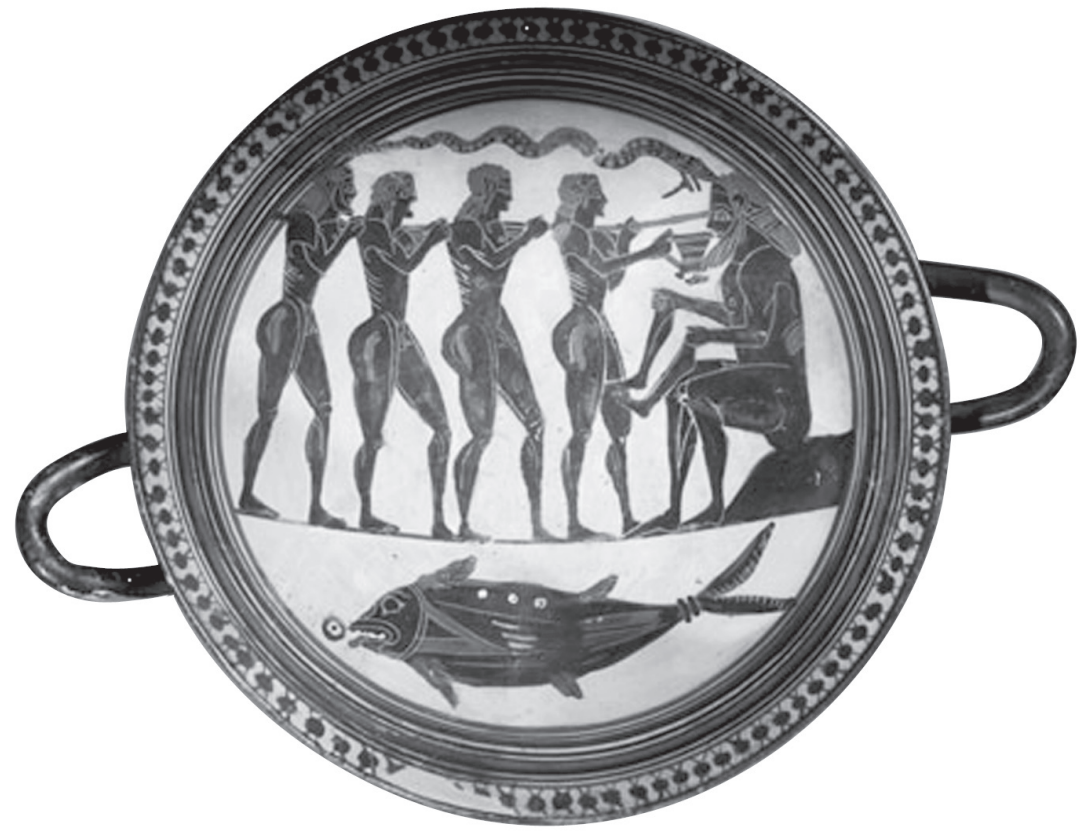

Figura 3. Taça espartana, atribuída ao "pintor do cavaleiro" (c. 560 a.C.) (disponível em: http://iconotheque.univ-paris1.fr/displayimage. php?album=72\&pid=2196\#top_display_media). 


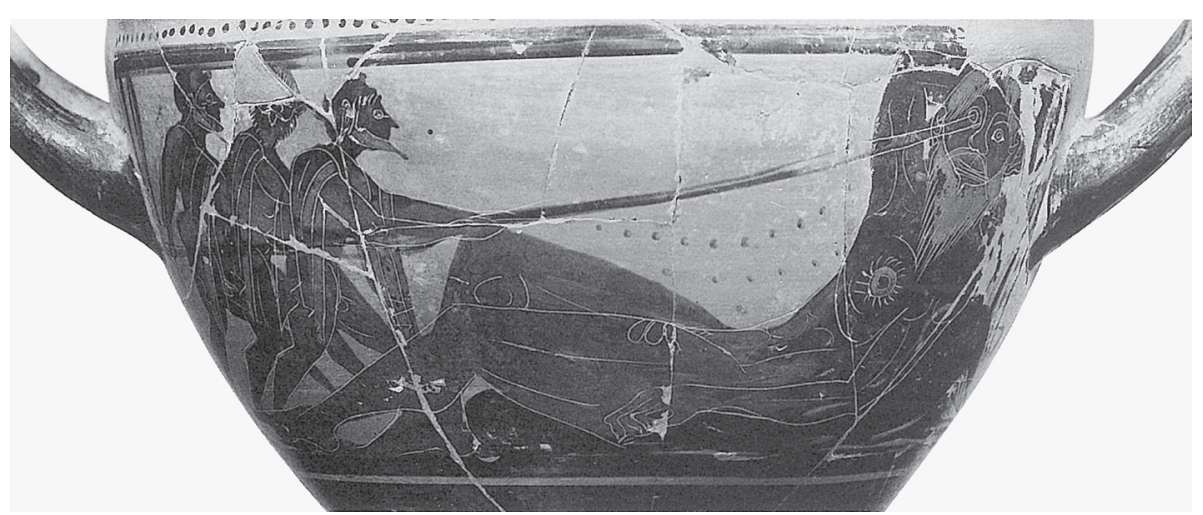

Figura 4. LIMC, K. 22: c. 500 a.C. (skyphos f.n., atribuído ao pintor de Teseu): Berlin, Antikensammlung, $\mathrm{n}^{\mathrm{o}} 306788$ (disponível em:http://iconotheque.univ-paris1.fr/displayimage. php?album=72\&pid=2198\#top_display_media).

Isto implica, por exemplo, validar uma relação de identidade, que não é de todo clara, entre texto e representação iconográfica ${ }^{27}$. Torna-se, por exemplo, difícil afirmar com certeza se os pintores conheciam a mesma versão que nós, hoje, conhecemos por intermédio da fixação dos textos. Mesmo assim, também parece arriscado dizer que as variações iconográficas correspondem a variações textuais ou que, simplesmente, são o resultado da liberdade do artista para expressar pormenores diferentes que não afectam, necessariamente, o conjunto, ou melhor, o reconhecimento, da narrativa. Não é, porém, ocasião para discutir se estes relatos são independentes, ou não, dos textos homéricos, embora o tema mereça um maior e melhor desenvolvimento em trabalhos futuros ${ }^{28}$.

\section{A NARRATIVA ATRAVÉS DAS LUCERNAS}

Actualmente, conhecemos um vasto leque de representações, de temas variados, plasmadas nos discos das lucernas romanas ${ }^{29}$. As cenas destes relevos consistem em representações mitológicas ou, simplesmente, da vida quotidiana,

${ }^{27}$ Tal não significa que se excluam elementos ditos "visualistas" como, por exemplo, a descrição do escudo de Aquiles na Ilíada. É particularmente útil a reflexão de M. Giles-Watson, "Odysseus and the ram in Art and (Con)Text: Arthur M. Sackler Museum 1994.8 and the Hero's Escape from Polyphemos", HSCPh 103 (2007) 555-577.

${ }^{28}$ Cf. J. Glenn, “The Polyphemus Folktale and Homer's Kylôpeia”, TAPhA 102 (1971) 133-181.

${ }^{29}$ W. Deonna, "L’Ornamentation des lampes romaines”, Revue Archéologique 26 (1927) 233-263; M M. Vegas, "Motivos decorativos en lucernas de disco romanas: sus antecedentes y paralelos", Pyrenae 2 (1966) 81-91; M ${ }^{\mathrm{a}}$ T. Amaré Tafalla, "Representaciones literarias...", 739-748; Ma T. Amaré Tafalla, "Una nueva representación de Ulises sobre lucernas romanas”, J. Nieto Ibáñez (coord.), Lógos hellenikós. Homenaje al profesor Gaspar Morocho Gayo (León 2003) I, 467-470; M. Amante Sánchez, "Representaciones iconográficas en lucernas romanas de la región de Murcia", Arte y poblamiento en el SE Peninsular (Murcia 1988) 213-254; S. Carretero Vaquero, "Lucernas romanas con paisaje de influencia alejandrina: temas pastoriles", BSEAA 55 (1989) 149-168; S. Carretero Vaquero, "Lucernas romanas con paisaje de influencia 
assumindo, aparentemente, um importante papel (de transmissão de conhecimentos, publicidade, divulgação, entre outros). Neste âmbito, saliente-se que as representações literárias também foram, pelo menos aparentemente, utilizadas, como foi exposto ${ }^{30}$. Com efeito, a partir do Alto-Império, concretamente desde o reinado de Augusto, verifica-se um considerável incremento da comercialização de produtos manufacturados, potenciado por mudanças técnicas na sua produção e, principalmente, por uma renovação do repertório morfológico da maioria das categorias cerâmicas.

É possível afirmar que estas produções pretendiam associar estética e funcionalidade. Neste sentido, também as lucernas foram alvo de mudanças profundas: apesar de se notar a ostentação de algumas cenas nos últimos tipos tardo-republicanos $^{31}$, limitadas a simples figurações geométricas e representações de fauna e flora, a maior inovação foi a introdução de uma assinalável variedade de temas nos relevos do disco.

Mas a vasta quantidade de representações lychnológicas, ${ }^{32}$ por vezes ambíguas ou inéditas, obriga-nos a questionar até que ponto conhecemos, de facto, a ideologia que se esconde por detrás do seu fabrico. Por outras palavras, para muitos dos relevos, ignoramos qual o objectivo que os seus fabricantes tinham com estas manifestações artísticas, além, como é óbvio, do comercial.

Como foi já reiteradamente avançado ${ }^{33}$, Ulisses é uma das personagens mais aclamadas na Antiguidade Clássica, juntamente com Hércules. Tal preferência, em período romano, não só está espelhada na iconografia das lucernas romanas, mas também nos relevos de outras categorias cerâmicas ${ }^{34}$, em

alejandrina: temas marítimos", BSAA 57 (1991) 193-214; I. Lazar, “An oil lamp from Slovenia depicting a Roman glass furnace”, Journal of Dalmatian Archaeology and History 99 (2006) 227-235.

${ }^{30} \mathrm{M}^{\mathrm{a}} \mathrm{T}$. Amaré Tafalla, "Representaciones literarias...", 739-748.

${ }^{31}$ M. Ricci, "Per una cronologia delle lucerne tardo-repubblicane", Rivista di Studi Liguri 2-4 (1973) 168-234; M. Ricci, "Le lucerne dei relitti sottomarini”, Rivista di Studi Liguri 57-58 (2001-2002) 305-420.

32 Este vocábulo corresponde, em certa medida, a um estrangeirismo que é utilizado pelas escolas francesa e inglesa, destacando-se a primeira, e que pretende individualizar o estudo da iluminação na Antiguidade. É utilizado aqui para as cerâmicas de iluminação, ainda que se reporte a todo o tipo de artefactos cuja finalidade era a de iluminar. O conceito tem origem no Latim "lychnus" (lâmpada). As palavras de Daniel Paunier, membro da Association Lychnologique Internationale, ajudam a compreender melhor a definição do conceito: "La science lychnologique, à l'instar de la céramologie, de la numismatique, de l'archéo-botanique ou de la paléo-trichologie, reste indissociable de l'archéologie: à partir de vestiges matériels, aussi modestes soient-ils, il convient essentiellement de saisir l'homme dans sa complexité et sa relation avec l'univers. Dans cette quête, longue et difficile, parfois désespérée, il importe d'améliorer sans cesse les outils de détermination et d'interprétation, de veiller à la multiplicité et à la diversité des approches, qu'il s'agisse d'analyses de laboratoire, d'études typologiques, chrono-quantitatives, technologiques, iconographiques ou économiques, sans oublier les dimensions culturelles et anthropologiques et tout en restant à l'écoute d'autres spécialistes.", AA.VV., Nouveautés Lychnologiques. Suisse, Lychnoservices (2003) 5.

${ }^{33} \mathrm{M}^{\mathrm{a}}$ T. Amaré Tafalla, "Una nueva representación...”, 467.

${ }^{34}$ H. Klumbach, "Lampenbilder und Terra Sigillata", Jahrbuch des Römisch-Germanischen Zentralmuseums zu Mainz 8 (1961) 185-194; O. Touchefeu-Meynier, Thèmes odysséens dans l'art Antique (Paris 1968). 
CARLOS PEREIRA / PEDRO ALBUQUERQUE

\begin{tabular}{|c|c|c|c|c|c|c|c|c|c|c|c|c|c|c|c|}
\hline 蒡 & -1 & - & - & $N$ & - & - & - & & $\ddot{i}$ & & & & - & - & - \\
\hline 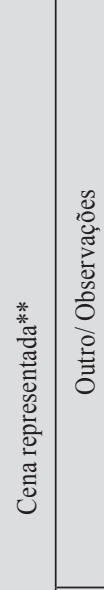 & 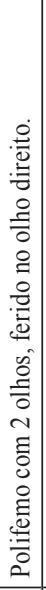 & & 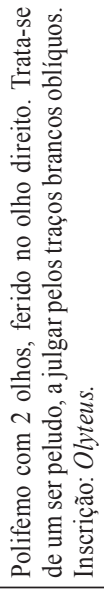 & 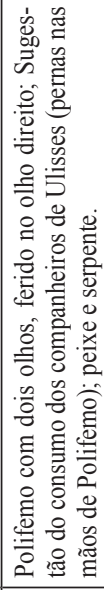 & 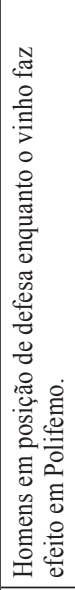 & 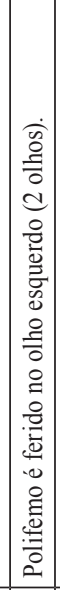 & 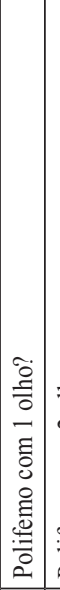 & 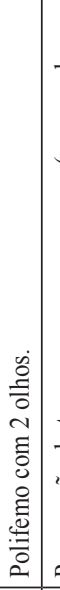 & 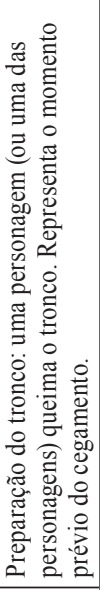 & 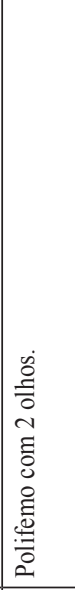 & 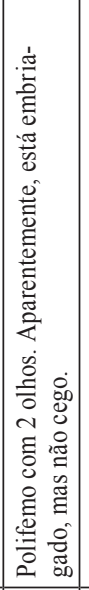 & 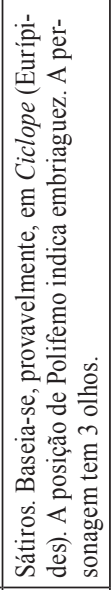 & & 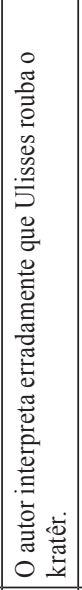 & \\
\hline 山 & & $x$ & & & & & & & & & & & & & \\
\hline 0 & $x$ & & & $x$ & & $x$ & $x$ & $x$ & $x$ & & & & & & \\
\hline$\infty$ & & & & & & & & & & & & & & & \\
\hline$\varangle$ & & & & & & & & & & & & & & & \\
\hline 피 & & & & & & & & & & & & & $x$ & $x$ & $x$ \\
\hline 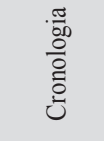 & $\begin{array}{l}0 \\
\dot{w} \\
0 \\
0 \\
0 \\
0\end{array}$ & $\mid \begin{array}{c}0 \\
\dot{x} \\
\tilde{D} \\
\vdots \\
\dot{0}\end{array}$ & 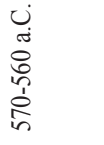 & 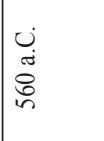 & & 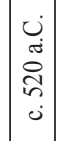 & 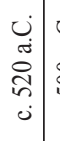 & 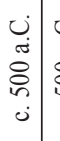 & 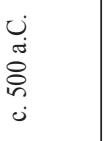 & $\begin{array}{l}0 \\
\tilde{j} \\
o \\
o \\
0 \\
0 \\
0\end{array}$ & 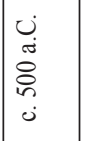 & 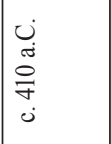 & 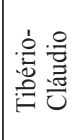 & 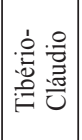 & 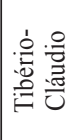 \\
\hline 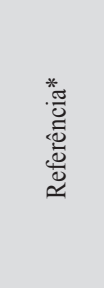 & 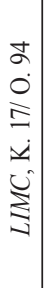 & 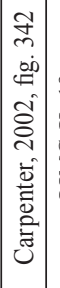 & 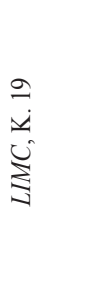 & 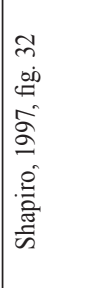 & 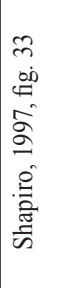 & 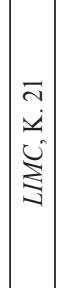 & 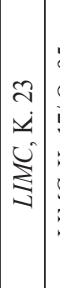 & 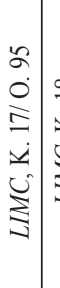 & 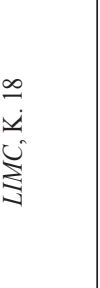 & 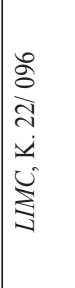 & 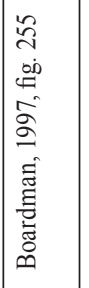 & 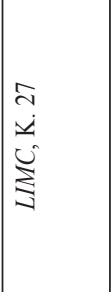 & 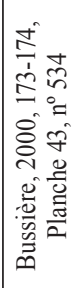 & 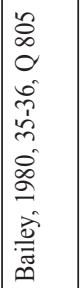 & 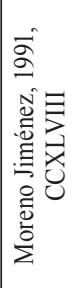 \\
\hline 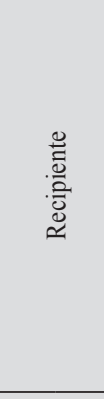 & 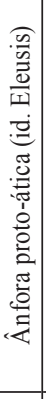 & 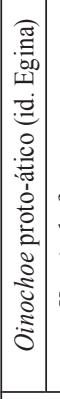 & 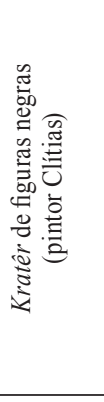 & 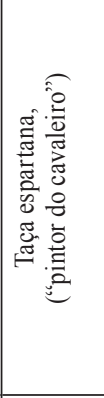 & & 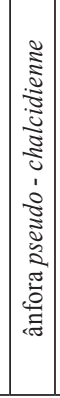 & 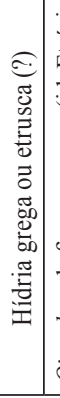 & 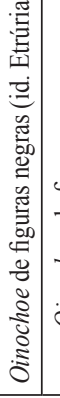 & 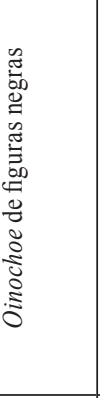 & 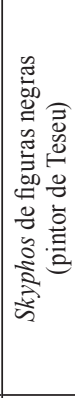 & 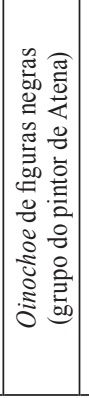 & 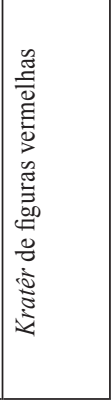 & 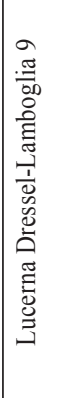 & 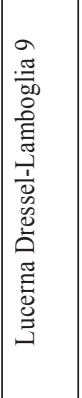 & 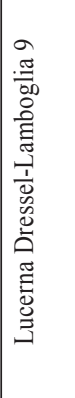 \\
\hline 歯 & - & $\sim$ & & \multicolumn{6}{|l|}{$m$} & \multicolumn{4}{|l|}{+} & \multicolumn{2}{|l|}{-} \\
\hline
\end{tabular}


A DIACRONIA DO ENCONTRO DE ULISSES COM O CICLOPE NO REPERTÓRIO...

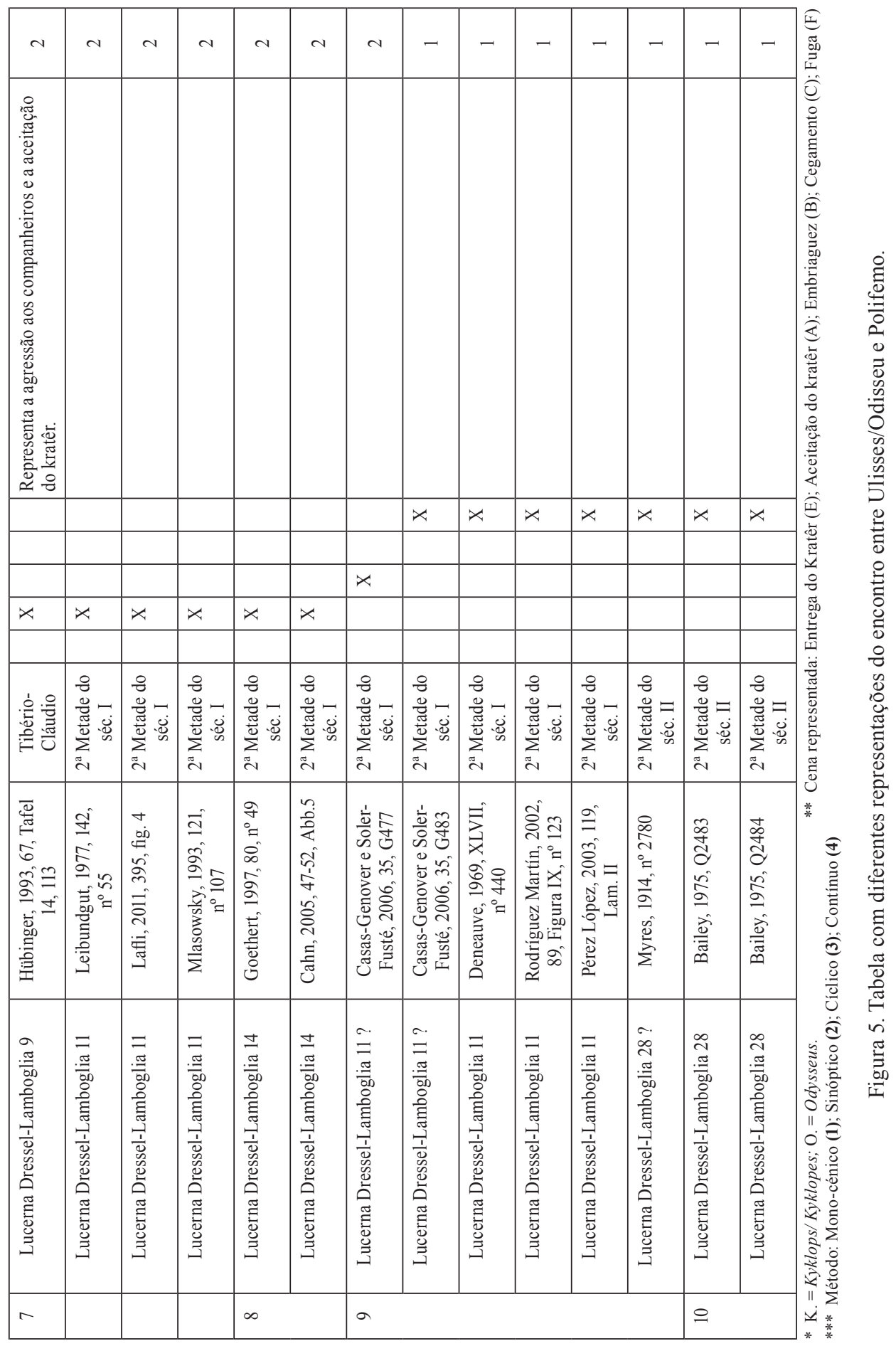


mosaicos ${ }^{35}$, ou mesmo na escultura ${ }^{36}$. É inegável que a cultura romana assimilou muito da tradição helénica e helenística, facto patente também nas representações de Ulisses, renovando muitas das representações gregas.

Talvez tenha sido esta grande durabilidade e projecção do herói que lhe valeu, em período romano, uma ampla representação de cenas lychnológicas que reproduzem distintos momentos das suas aventuras. Algumas dessas iconografias reproduzem o encontro de Ulisses com Polifemo, narrado por um considerável conjunto de relevos, alguns já analisados ${ }^{37}$, e que são aqueles que nos interessam aqui. Efectivamente, e como foi já referido, as aventuras de Ulisses foram amplamente estampadas nas lucernas, transmitindo, de uma forma relativamente contínua, o seu regresso a Ítaca.

A narrativa lychnológica da aventura do herói encontra, contudo, abundantes hiatos e carece ainda de cenas que a complementem, embora possamos encontrar essas iconografias em outros âmbitos. O episódio que parece estar, de momento, mais completo é, realmente, o encontro de Ulisses com Polifemo, patenteado por relevos que dão uma leitura quase ininterrupta a esse episódio. Duas dessas representações iconográficas eram já bem conhecidas (figs. 1 a 5): Ulisses a oferecer o Kratêr com vinho ao Ciclope, e Ulisses a escapar-se do gigante sob o ventre do carneiro. A análise que ora se apresenta permite enquadrar duas outras representações que, embora já conhecidas, complementam a narrativa homérica. Referimo-nos às representações isoladas de ambos os intervenientes. Este ensaio pretende dar, assim, seguimento aos estudos de outros autores, chamando à colação lucernas já divulgadas e às que tivemos acesso. Contudo, admitimos que a vastíssima bibliografia, alguma de difícil acesso, impossibilitou uma análise de todos os materiais já publicados.

De momento, importa fazer uma descrição destas representações dando especial destaque à evolução narrativa e artística, ressaltando, simultaneamente, os problemas que elas aportam à leitura final. Posteriormente, efectuaremos uma análise mais prática, tendo em atenção a cronologia e morfologia das peças onde surgem, simplificando, assim, a interpretação final.

O encontro de Ulisses com Polifemo está representado nos discos das lucernas romanas em, pelo menos, quatro cenas distintas. Ulisses que leva o Kratêr ao Ciclope (fig. 7); Ulisses oferecendo o Kratêr e Polifemo que o aceita (fig. 8); Polifemo

${ }^{35}$ B. Pace, I mosaici di Piazza Armerina (Roma 1955); S. Settis, "Per l’interpretazione di Piazza armerina", MEFR 87.2 (1975) 937; P. Felde, "Zur dionysischen Präsenz in Mosaikbildern der spätrömischen Villa bei Piazza Armerina und zu einem einheitlichen, übergeordneten Konzeptionsgedanken", Dialogues d'histoire ancienne, Vol. 32, 1 (2006) 38.

${ }^{36}$ V. Tusa, I sarcofagi romani in Sicilia (Palermo 1995) 22-23; H. Weis, "Odysseus at Sperlonga: Hellenistic Hero or Roman Foil?", N. De Grummond, B. Rigdway (eds.), From Pergamon to Sperlonga. Sculpture and Context (Berkeley 2000).

${ }^{37} \mathrm{M}^{\mathrm{a}} \mathrm{T}$. Amaré Tafalla, "Representaciones literarias...", 742-743; $\mathrm{M}^{\mathrm{a}} \mathrm{T}$. Amaré Tafalla, "Representación de Ulises en el episodio de las sirenas sobre un asa de lucerna romana", Boletín del Museo de Zaragoza 8, (1989) 21-30; Mª T. Amaré Tafalla, "Una nueva representación...”, 468. 
bebendo o vinho (fig. 9); Ulisses em fuga sob o ventre do carneiro (fig. 10). Sem dúvida que, das cenas homéricas representadas nas lucernas, o canto $I X^{38}$ foi o que gozou de um maior número de relevos nestes materiais, e, através da soma destas representações, é possível reconstituir este encontro quase na totalidade.

A narrativa lychnológica do episódio em apreço começa por um relevo onde surge uma personagem, centrada no disco, claramente com um Kratêr na mão e em atitude de oferenda. Sem dúvida que se trata de uma representação de Ulisses, aparentando estar em movimento, e subindo o Kratêr com ambas as mãos. Além disso, veste uma túnica inspirada no exomis grego e tem, na cabeça, o típico gorro grego, o pilos. Esta atitude delata, em nosso entender, que entrega o objecto a alguém que está em uma posição muito superior à sua. Note-se, por exemplo, que Polifemo apresenta, no caso das cerâmicas anteriormente apresentadas, um tamanho superior ao dos seus opositores, respeitando a sua descrição como um gigante. Assim, é possível afirmar, não sem as devidas reservas, que a personagem a que se dirige Ulisses é Polifemo, o Ciclope.

O principal argumento que justifica a identificação desta personagem com Ulisses assenta sobre a aplicação do mesmo relevo na cena seguinte. Por outras palavras, o relevo de Ulisses, isolado no disco da lucerna, foi utilizado também na representação em que Polifemo aceita o vinho que aquele lhe oferece. Não será descabido pensar, por isso, que o mesmo artífice que produziu o relevo em que Ulisses está sozinho, terá sido o mesmo que (re)produziu a cena onde Ulisses dá o Kratêr a Polifemo e este o aceita. O estilo artístico é, claramente, o mesmo. As únicas diferenças do relevo de Ulisses são as suas dimensões e a posição que assume no disco da lucerna, sendo todos os restantes pormenores e características da personagem iguais.

Ainda que este estudo não se apoie em nenhum conjunto lychnológico em concreto, mas sim em exemplares já publicados, sabemos que os estudos gerais de lucernas romanas delatam o aparecimento de complexas representações nestes materiais apenas a partir do reinado de Augusto. Já referimos que as representações de Ulisses e Polifemo não aparecem unicamente nas lucernas. São sobejamente conhecidas as esculturas da villa de Tibério ${ }^{39}$, em Sperlonga, o relevo de sarcófago (fig. 6), datado do século III, da Catânia ${ }^{40}$, que aliás possibilitou a reconstituição das esculturas de Sperlonga, ou ainda o mosaico da villa romana de Casale ${ }^{41}$, na Sicília. Não obstante, parece que estas representações, tanto na escultura como na mosaística, pretendem apresentar simultaneamente as já referidas passagens do relato (a entrega do Kratêr, a embriaguez do Ciclope e o seu cegamento). Nas

${ }^{38}$ T. Bulfinch, História de dioses..., 314-317.

${ }^{39} \mathrm{H}$. Weis, "Odysseus at Sperlonga...., 125-130.

${ }^{40} \mathrm{~V}$. Tusa, I sarcofagi romani..., 22-23.

${ }^{41}$ B. Pace, I mosaici di Piazza ...; S. Settis, “Per l'interpretazione di...”, 937; P. Felde, “Zur dionysischen Präsenz in...", 38. 


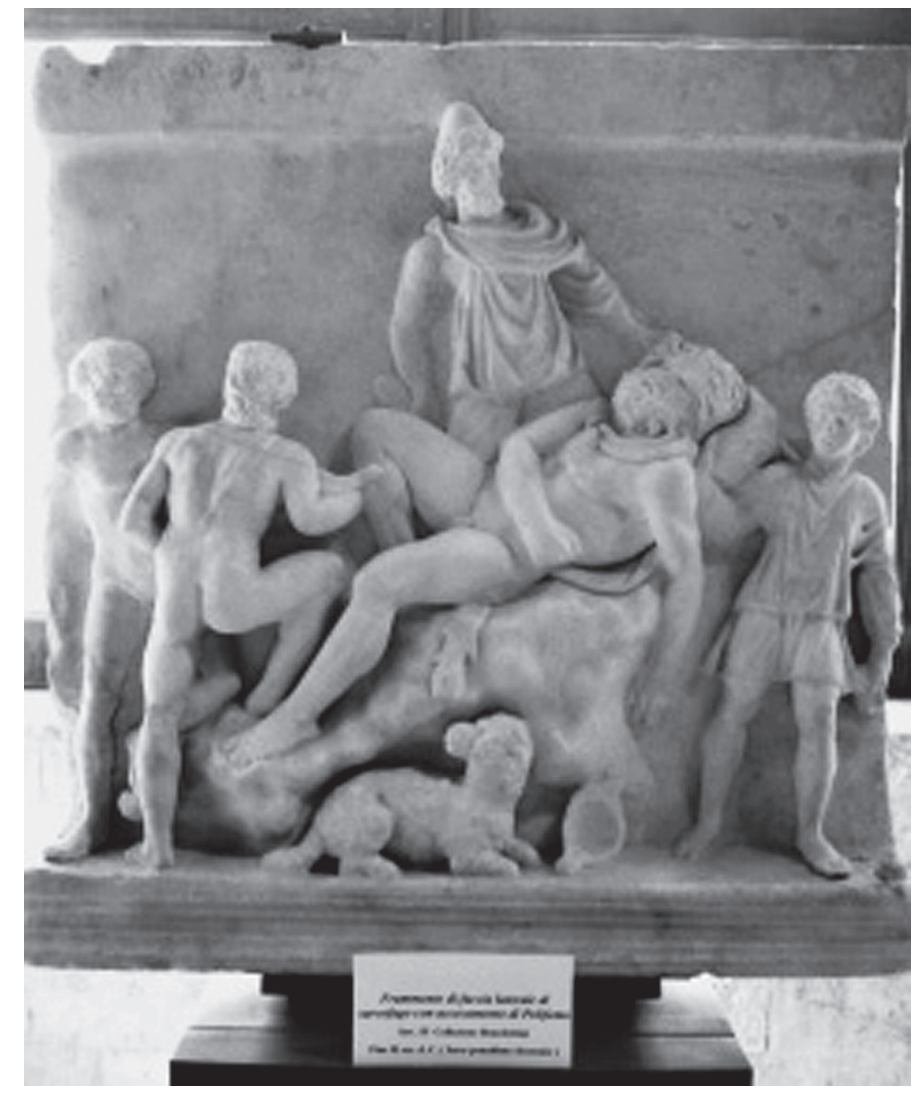

Figura 6. Lateral de um sarcófago romano da Catânia, que representa a embriaguez de Polifemo e o seu consequente cegamento (Tusa, 1995, 22-23).

lucernas a situação é ligeiramente distinta. Além da óbvia portabilidade que permitiam, e a consequente maior disseminação das representações iconográficas, parece que foi intencional a exposição, isolada, de cada acção do herói.

O século I d.C. é, de facto, o momento chave em que estas cenas parecem surgir nos materiais lychnológicos, com variadas figuras e em abundância. Não obstante a informação que temos hoje sobre a produção de lucernas, é bastante difícil comprovar as figlinae onde estes relevos foram originalmente fabricados. De momento, apenas podemos garantir que as cenas que serviram de protótipo foram produzidas pelo mesmo indivíduo.

É, possivelmente, neste âmbito que surgiram as primeiras lucernas romanas com representações de Ulisses. A cena que descrevemos antes, Ulisses isolado no disco com o Kratêr na mão, aparece em exemplares de tipo Dressel-Lamboglia $9^{42}$, com uma cronologia que tem vindo a ser balizada entre os reinados de

${ }^{42}$ H. Dressel, Lucernae formae, C.I.L. XV, Vol. II: 1 (1899); N. Lamboglia e A. Beltrán, “Apuntes sobre cronología cerámica", Caesaraugusta 3 (1952) 87-89. 
Figura 7. Ulisses, com o kratêr na mão, encaminhando-se para o oferecer a Polifemo (Bailey, 1980, 35-36, Q805).

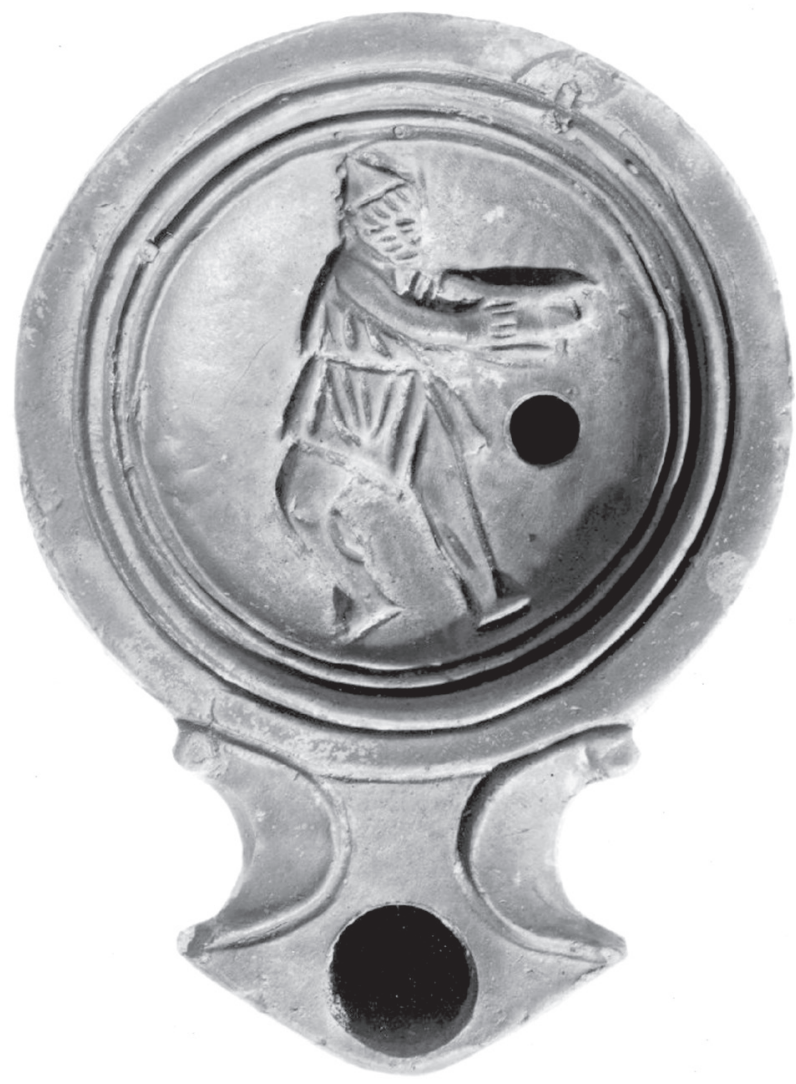

Augusto e Cláudio, e em lucernas do tipo precedente, Dressel-Lamboglia 11. No entanto, fora da Península Itálica estas representações parecem centrar-se maioritariamente entre os reinados de Tibério e Cláudio ${ }^{43}$, no caso do tipo 9.

Chamamos à colação alguns exemplos de Ulisses portando o Kratêr, como tema único e central no disco, nomeadamente aquele que foi dado à estampa por Bussière $^{44}$ ou um outro, do British Museum, que Bailey interpretou como se a personagem roubasse o Kratêr ao Ciclope $^{45}$ (fig. 7), facto que é contradito pela literatura. Na Bética conhece-se um exemplar de Sevilha descrito como "Ulises mostrando una copa a Polifemo"46.

${ }^{43} \mathrm{H}$. Walters, Catalogue of the Greek and Roman lamps in the British Museum (London 1914) pl. XVII, n ${ }^{\circ}$ 547; D. Bailey, A Catalogue of the Lamps in the British Museum, II. Roman Lamps made in Italy (London 1980) 35-36, Q 805; J. Bussière, Lampes antiques d'Algérie (Montagnac 2000) 173, Planche $18, \mathrm{n}^{\circ} 63$.

${ }^{44} \mathrm{~J}$. Bussière, Lampes antiques..., 173-174, Planche 43, nº 534.

${ }^{45}$ D. Bailey, A Catalogue of the Lamps..., 35.

${ }^{46}$ F. Moreno Jiménez, Las lucernas romanas de la Bética (Madrid 1991) III, 1795, CCXLVIII. 
Parece credível que a grande popularidade que a figura de Ulisses alcançou ${ }^{47}$, quer tenha sido pela literatura como pelo teatro, justifica a sua ampla propagação, inclusive pelos oleiros que fabricavam lucernas. Como adiantámos antes, num momento inicial estas iconografias podem ter estado confinadas à Península Itálica. Mas à medida que vão ganhando cada vez mais notoriedade, os relevos de Ulisses vão sendo progressivamente exportados para as restantes áreas do Império, ainda em momento centrado ao século I, nomeadamente para as províncias hispânicas, Norte africanas e do Sul da Gália, agora associadas a uma outra representação: Ulisses entregando o Kratêr a Polifemo. Com o exposto, parece credível admitir uma influência itálica para as duas primeiras cenas desta narrativa, sendo mais complexo intuir a mesma realidade para as restantes.

Nesta cena, Ulisses mantém rigorosamente as mesmas características, mas agora está perante Polifemo, a quem entrega o Kratêr. Dos quatro relevos que descrevem o encontro entre ambas as personagens, este é, talvez, o mais bem conhecido na bibliografia da especialidade. Esta análise não traz nada de novo sobre a sua descrição. Contudo, a sua inclusão é necessária para que possamos compreender o seu contexto iconográfico e cronológico na leitura final. É nesta exposição lychnológica que Polifemo aceita o vinho, com a mão direita, enquanto, na outra, segura um dos companheiros de Ulisses pelo braço. Está sentado numa rocha, despido e, geralmente, barbado, características que, como vimos anteriormente, podem ser relacionadas com a ideia de desumanidade que a obra homérica, aparentemente, pretende transmitir.

Também esta representação aparece nos tipos Dressel-Lamboglia $9^{48}$ e 11, somando-se o 14 (fig. 8), com especial incidência no segundo tipo. Não será descabido afirmar que a disseminação destas cenas foi potenciada pelo grande sucesso que logrou o tipo Dressel-Lamboglia 11, pelo menos na parte ocidental do Império. Assim, terá sido maioritariamente durante meados e a segunda metade do século I que estas cenas foram divulgadas. A comprová-lo, encontramos alguns exemplares onde Ulisses entrega o Kratêr a Polifemo, que por sua vez imobiliza um dos companheiros do primeiro ${ }^{49}$. É possível, contudo, surgirem alguns exemplares em que Polifemo apenas aceita o vinho. A diferença entre ambas reside unicamente no facto de uma ser sinóptica, representação de Polifemo que come

${ }^{47}$ E. Kenney, W. Clausen, The Cambridge History of Classical Literature. 2. Latin Literature (Cambridge 1996) 289.

${ }^{48}$ U. Hübinger, Die antiken Lampen des akademischen Kunstmuseums der Universität Bonn (Berlin 1993) 67, Tafel 14, $n^{\circ} 113$.

${ }^{49}$ A. Leibundgut, Die römischen Lampen in der Schweiz (Bern 1977) 142, n 55; K. Goethert, Römische Lampen und Leuchter. Auswahlkatalog des Rheinischen Landesmuseums Trier (Trier 1997) 80, n. ${ }^{\circ}$ 49; E. Lafli, "Five early imperial lampes from the museum of Tarsus in Cilicia (Southeastern Turkey)", in D. Frangié, J.-F. Salles (eds.), Lampes antiques du Bilad Es-Sham, Jordanie, Syrie, Liban, Palestine (Paris 2011) 395, Fig. 4; E. Cahn, "Die production römischer bildlampen in Köln", L. Chrzanovski (dir.), Lychnological Acts 1. Actes du ler congrès international d'études sur le luminaire antique (Montagnac 2005) 47-52, Abb. 5; A. Mlasowsky, Die antiken Tonlampen im Kestner-Museum Hannover (Hannover 1993) 121, nº 107. 
Figura 8. Ulisses a entregar o kratêr a Polifemo, que o aceita (Goethert, $\left.1997,80, n^{\circ} 49\right)$.

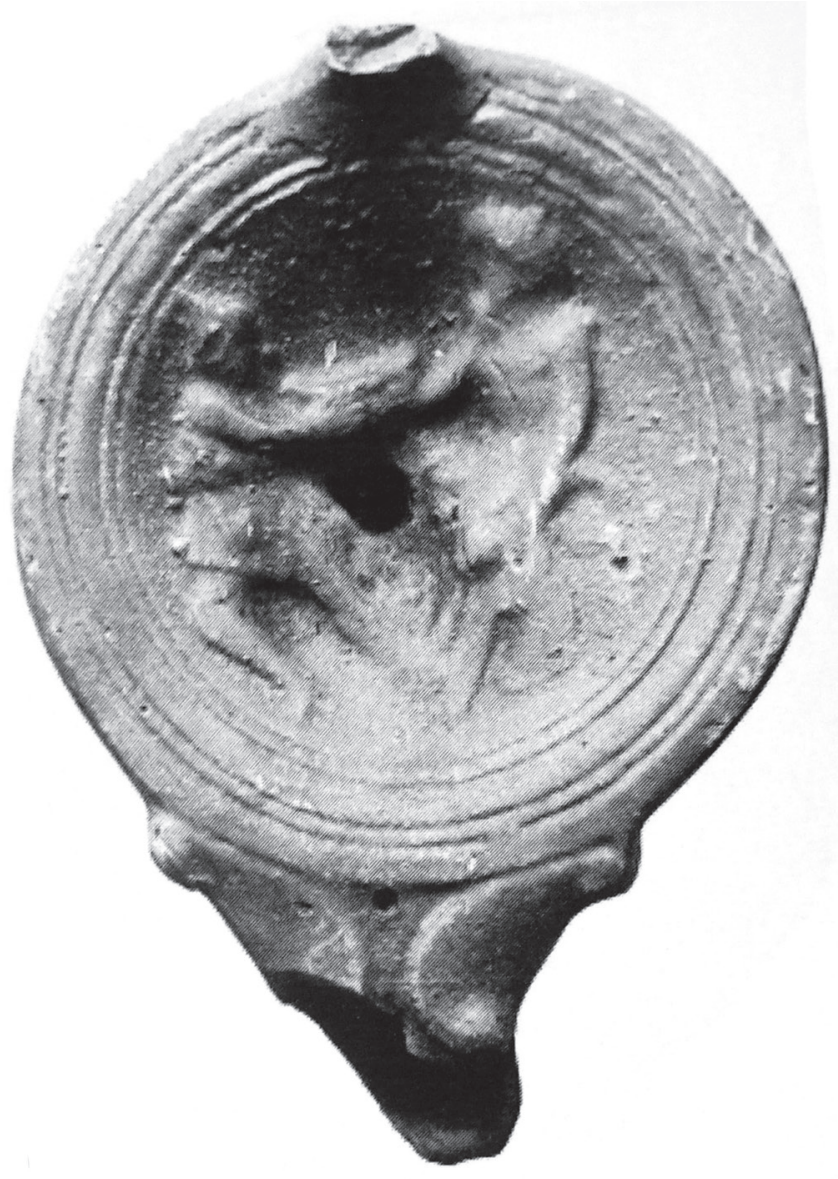

os companheiros do herói e a aceitação do Kratêr, enquanto a restante parece ser mono-cénica, representando apenas o segundo caso.

Mas a desumanidade do Ciclope é contradita pela inocência que o impele a aceitar o Kratêr e ingerir o vinho. Efectivamente, é esta a cena que encontramos nas lucernas, imediatamente a seguir à anterior. Polifemo aparece agora sozinho, centrado no disco da lucerna, com o Kratêr na mão. Na maioria dos casos continua a agarrar o companheiro de Ulisses, corroborando a continuidade descritiva da aventura. Tal como foi verificado na análise comparativa entre a figura de Ulisses sozinho ou acompanhado por Polifemo, também as figurações de Polifemo, quer isolado quer na presença de Ulisses, não apresentam qualquer variação artística. Tal situação pode fazer suspeitar que os três relevos foram, com efeito, elaborados pelo mesmo artífice, ou pelo menos na mesma figlinae. No entanto, embora não possamos assegurar tal facto, o certo é que estas três representações conviveram durante a segunda metade do século I. 
O grande inconveniente desta cena em concreto reside, contudo, na substituição do grego moribundo, que o Ciclope segura, por uma clava. Conhecem-se, de facto, alguns exemplares que ostentam uma representação rigorosamente igual, mas que a personagem tem na mão esse artefacto de madeira, é o caso de uma lucerna gaulesa, depositada no museu de Reáttu, em Arles ${ }^{50}$ (fig. 9b) ou de uma outra ainda, de Cartago ${ }^{51}$, fabricadas sobre lucernas de tipo Dressel-Lamboglia 11. Esta disparidade tem potenciado diferentes leituras destes relevos ${ }^{52}$, nem sempre claras. Se, por um lado, podemos associar a clava a Polifemo, já que esta personagem também aparece em algumas cerâmicas gregas com este artefacto ${ }^{53}$, também pode ser facilmente associada à representação de Hércules Epitrapezios. Por ora, e em nosso entender, não é ainda claro se estes relevos correspondem a um ou a outro caso, ainda que admitamos uma maior semelhança com o último. Não obstante, é indiscutível que, quando a personagem segura um moribundo, trata-se de Polifemo (fig. 9a; cf. fig. 3).

Mais uma vez, é nas lucernas Dressel-Lamboglia 11 que podemos encontrar estas representações, tanto de Polifemo ${ }^{54}$ como de Hércules. Esta forma é, sem dúvida alguma, a única que exibiu a totalidade das representações sobre o encontro de Ulisses e Polifemo, demonstrando que foi durante a segunda metade do século I que a narrativa se completou. A forma antecedente, como vimos, apenas portava as representações de Ulisses sozinho, com o Kratêr, ou oferecendo o vinho ao Ciclope.

A iconografia lychnológica carece, até ao momento, da representação de Ulisses cegando o Ciclope, como acontece abundantemente na cerâmica grega (figs. 1,3 e 4). Desconhecemos qual o motivo, ou os motivos, que terá potenciado a não eleição desta cena pelos fabricantes de lucernas. Certo é que não podemos atribuir esta inexistência à complexidade que implicava a elaboração da cena no limitado espaço dos discos das lucernas. Lembramos a existência de exemplares que ostentam a representação de Ulisses preso ao mastro da sua embarcação ${ }^{55}$, para resistir ao canto das sereias, que obrigou a um elevado trabalho artístico. Por outro lado, ainda que não seja abundante, a representação de Ulisses e os companheiros a cegar Polifemo foi reproduzida na escultura. As mais conhecidas são, sem dúvida

${ }^{50}$ J. Bonnet, C. Delplace, "Etude d'une production de lampes en Gaule”, Gallia 41.1 (1983) 175, Fig. 3 , n. ${ }^{\circ} 2$.

${ }^{51}$ J. Deneauve, Lampes de Carthage (Paris 1969) Plate XLVII, n. ${ }^{\circ} 442$.

${ }^{52} \mathrm{M}^{\mathrm{a}} \mathrm{T}$. Amaré Tafalla, "Representaciones literarias...", 742-743; B. Petitot, Catalogue des lampes grecques et romaines. Les collections du Musée de l'Arles Antique (Arles 2000) 55, nº 84.

${ }^{53}$ L. Giuliani, Image and Myth: A History of Pictorial Narration in Greek Art (Chicago-London 2013) $137-138$.

${ }^{54}$ J. Casas-Genover, V. Soler-Fusté, Lucernas romanas en el extremo nordeste de la Península Ibérica (Oxford 2006) 35, G477.

${ }^{55} \mathrm{~F}$. Rodríguez Martín, Lucernas romanas del museo nacional de arte romano (Mérida) (Mérida 2002) 89, Figura IX, nº 124. 

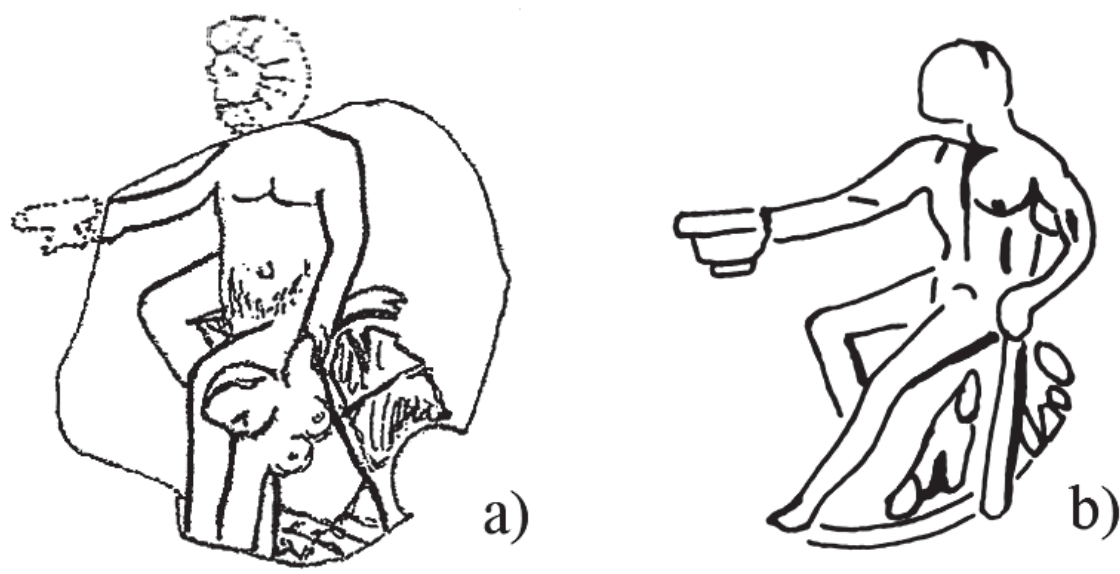

Figura 9. a) Representação de Polifemo embriagado, que segura um companheiro de Ulisses e, simultaneamente, o kratêr (Casas-Genover e Soler-Fusté, 2006, 35, G477); b) A mesma representação mas agora com a clava na mão, que vem sendo interpretada ora como Polifemo (Bonnet e Delplace, 1983, Fig. 3, nº 2), ora como Hércules Epitrapezios (Petitot, 2000, 55, nº 84).

alguma, aquelas que foram encontradas em Sperlonga ${ }^{56}$, datadas do século I. Contudo, existem outras, menos conhecidas, que, tal como as representações efectuadas nas cerâmicas gregas, são claramente sinópticas. Referimo-nos concretamente ao fragmento de sarcófago encontrado na Catânia ${ }^{57}$, datado do século III, que serviu de modelo para a reconstituição da cena de Sperlonga, ou às esculturas da Baia $^{58}$, na Campânia, que exibem os mesmos intervenientes. Também fizemos já referência ao sobejamente conhecido mosaico da Piazza Amerina ${ }^{59}$, que tem a particularidade de Polifemo surgir com um terceiro olho na fronte ${ }^{60}$.

Embora a privação de visão de Polifemo não esteja presente na iconografia lychnológica, a fuga de Ulisses e seus companheiros da gruta do gigante não é incomum. Trata-se da última cena estampada nas lucernas sobre este episódio homérico, no qual Ulisses prende os companheiros ao ventre das ovelhas, e ele próprio se ata ao ventre de um carneiro, para, pela manhã, fugirem da gruta. Parece, pois, evidente que na fig. 10 a representação de um carneiro com um indivíduo, sem dúvida Ulisses, sob o seu ventre é um testemunho desta cena.

${ }^{56}$ H. Weis, "Odysseus at Sperlonga...”; A. Stewart, “To entretain an emperor: Sperlonga, Laokoon, and Tiberius at the dinner-table", JRS 57 (1977) 76-90.

${ }^{57}$ V. Tusa, "I sarcofagi romani..., 22-23.

${ }^{58}$ P. Miniero, F. Zevi, Museo archeologico dei campi flegrei. Catalogo generale: Liternum, Baia, Miseno (Napoli 2008) 156-158.

${ }^{59}$ B. Pace, I mosaici di Piazza ...; S. Settis, "Per l'interpretazione..., 937; P. Felde, “Zur dionysischen Präsenz in...," 38.

${ }^{60}$ Veja-se $L I M C$, s.u. Kyklops/Kyklopes, $\mathrm{n}^{\mathrm{o}} 27$, onde existe uma imagem de Polifemo com um terceiro olho. 
Esta cena está bem atestada nos conjuntos de materiais de Ampúrias ${ }^{61}$, de Cartago $^{62}$ e ainda nos dos museus de Mérida ${ }^{63}$ e Cádis ${ }^{64}$. Curiosamente, embora também apareça em lucernas da série de volutas, esta é a única cena que se continua a ser eleita para figurar nos discos das lucernas da série de disco ${ }^{65}$ (fig. 10), prolongando-se a sua utilização até momento centrado na segunda metade do século II.

\section{Algumas CONSIDERAÇÕES}

Da categoria iconográfica lychnológica de mitos e lendas Ulisses foi, sem dúvida alguma, uma das personagens que mais figurou nos discos das lucernas romanas. Já nomeámos outros episódios que foram dados à estampa. Contudo, o encontro com Polifemo parece ter conseguido uma maior representatividade, o que lhe valeu uma sequência de cenas que se assemelham a autênticos "diapositivos" que narram uma história. A justificação desta preferência pode estar na valorização da astúcia e inteligência do herói ${ }^{66}$ perante situações de clara desvantagem, ou mesmo noutras interpretações que por agora escapam. Qualquer afirmação neste sentido é, porém, especulativa.

Estranhamos sobremaneira a ausência do cegamento do Ciclope, representada por outros artífices na Península Itálica. No entanto, a ausência da principal façanha de Ulisses frente a Polifemo talvez possa ser justificada pelas representações teatrais que, durante o Alto-Império, aderiram consideravelmente à comicidade satírica ${ }^{67}$, que pretende engrandecer principalmente a embriaguez do gigante. Neste âmbito, refira-se a conhecida sátira de Varrão ${ }^{68}$, Sesculixes.

Os poucos exemplares que este estudo pôde trazer à colação não representam a totalidade de materiais que, seguramente, existe. Muitos conjuntos de lucernas permanecem inéditos e outros podem estar publicados em revistas locais, dissimulados com títulos que não denunciam a sua existência. Não obstante, aqueles que foram aqui indicados demonstram uma disseminação geográfica consideravelmente ampla. Refira-se que esta disseminação foi muito potenciada pela grande aceitação que teve a lucerna de tipo Dressel-Lamboglia 11, da série de volutas, e que ostenta a maior parte das cenas que citámos.

\footnotetext{
${ }^{61} \mathrm{~J}$. Casas-Genover, V. Soler-Fusté, Lucernas romanas..., 35, G483.

62 J. Deneauve, Lampes de Carthage..., Plate XLVII, n. ${ }^{\circ} 440$.

${ }^{63}$ F. Rodríguez Martín, Lucernas romanas..., 89, Figura IX, nº 123.

${ }^{64}$ I. Pérez López, "Avance del estudio de las lucernas romanas del museo de Cádiz”, Anuario Arqueológico de Andalucía, Actividades Sistemáticas y Puntuales, Informes y Memorias 2000 (2003) 119, lam. II.

${ }^{65} \mathrm{~J}$. Myres, Handbook of the Cesnola Collection of Antiquities from Cyprus (New York 1914) $\mathrm{n}^{\circ}$ 2780; D. Bailey, Catalogue of the Lamps in the British Museum, I-IV (London 1975) Q 2483 e Q2484;

${ }^{66} \mathrm{M}^{\mathrm{a}} \mathrm{T}$. Amaré Tafalla, "Una nueva representación...”, 468.

${ }^{67}$ P. Fedeli, "La metamorfosis del héroe: del Odiseo homérico al Ulises de la sátira y de la novela", R. Pestano Fariña (Coord.), Paradigmas éticos y estéticos (La Laguna 2011) 51-65.

${ }^{68}$ E. Kenney, W. Clausen, The Cambridge History..., 289.
} 
Figura 10. Ulisses escapando de

Polifemo, sob o ventre do carneiro (Bailey, 1975, Q2483, disponível no site: http://www. britishmuseum. org/research/ collection_online).

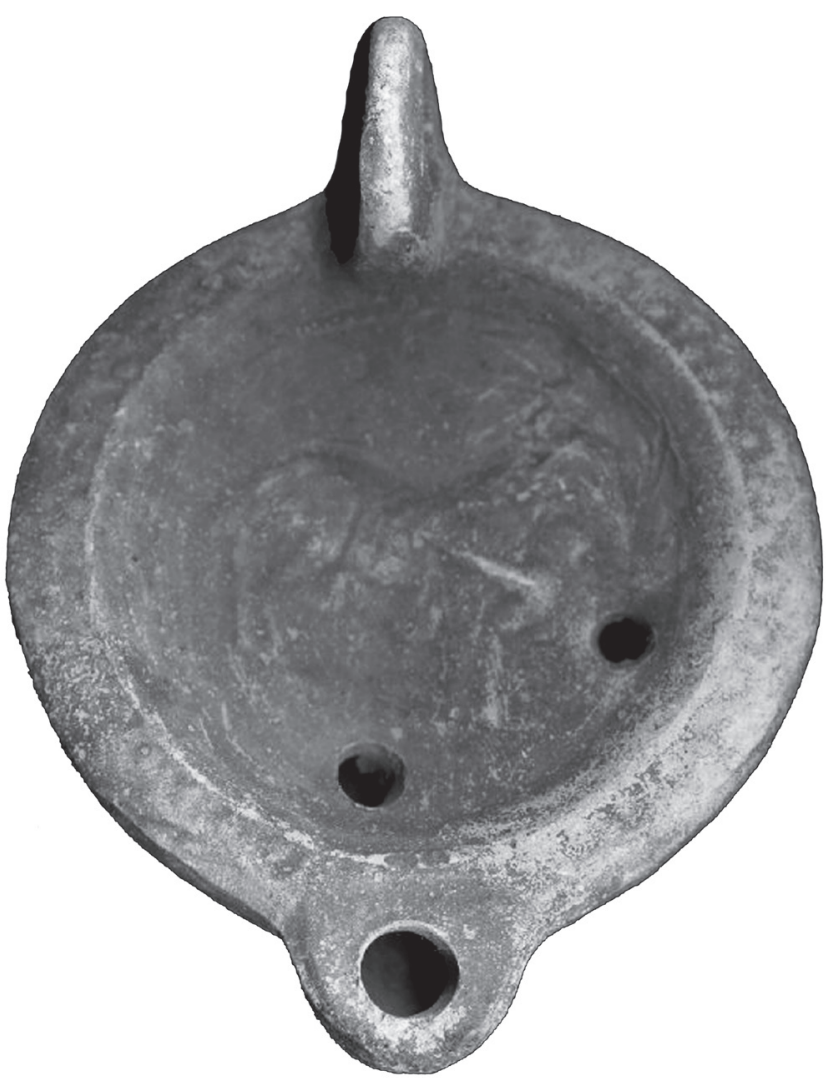

De facto, foi durante o século I d.C. que as representações iconográficas de Ulisses e Polifemo foram mais consumidas, juntamente com as lucernas. Isso não significa, todavia, que a partir da viragem do século I para o II estas reproduções tenham deixado de ser fabricadas. Continuam a ser paulatinamente aplicadas nos discos das lucernas, mas somente duas das cenas, concretamente Ulisses sob o ventre do carneiro ${ }^{69}$, em lucernas de tipo Dressel-Lamboglia 20 e 28, e a representação de Polifemo sentado na rocha ${ }^{70}$, em lucernas Dressel-Lamboglia 20. Esta redução das iconografias lychnológicas dedicadas a Ulisses e Polifemo já havia sido notada, atribuindo-se à “...disminución progresiva que experimenta el tamaño del discus." ${ }^{71}$. Não obstante, cremos que esta redução se deve a outros factores, entre eles as emergentes produções provinciais hispânicas que elegiam outros motivos em detrimento dos que aludem à literatura grega.

${ }^{69}$ D. Bailey, Lamps in the Victoria and Albert Museum (Athens 1965) 47, n. ${ }^{\circ} 129$; D. Bailey, A Catalogue of the Lamps in the British Museum, I. Greek, Hellenistic and early pottery lamps (London 1975) Q 2483.

${ }^{70} \mathrm{~J}$. Bussière, Lampes antiques..., 172, Planche 59, n. ${ }^{\circ}$ 2117; D. Bailey, A Catalogue of the Lamps..., 34-35, Plate 74, Q 1334.

${ }^{71} \mathrm{M}^{\mathrm{a}}$ T. Amaré Tafalla, "Representaciones literarias...", 743. 
Admitimos que, durante o século I, as produções provinciais hispânicas eram já uma realidade bem visível. Limitavam-se, porém, a reproduzir maioritariamente os produtos itálicos. A partir do século II, a realidade produtiva lychnológica na Hispânia mantem-se, mas desde então as lucernas mudam consideravelmente o repertório morfo-iconográfico, delatando produtos com outra influência ${ }^{72}$. Em todo o caso, não é o objectivo deste estudo a análise das figlinae que produziram lucernas romanas, senão as representações que algumas ostentam sobre o encontro de Ulisses com Polifemo, até porque, intuindo que a influência destas cenas está nos produtos itálicos, que rapidamente foram copiadas nas oficinas peninsulares, as pastas assumiram as características dessa área geográfica.

${ }^{72}$ C. Pereira, "Reflexiones sobre el decaer del comercio de lucernas romanas en el Occidente peninsular", Onoba, Revista de Arqueología y Antigüedad (no prelo). 